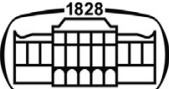

AKADÉMIAI KIADÓ

\title{
Surveying the relation between the means of infant feeding and motor development in Hungary
}

\section{Developments in Health Sciences}

3 (2020) 3, 65-71

DOl:

$10.1556 / 2066.2020 .00012$

(c) 2020 The Author(s)

\section{ORIGINAL RESEARCH} PAPER

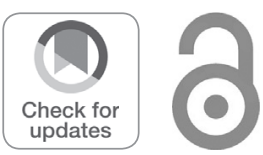

\author{
M. KÁDÁR ${ }^{1,2^{*}}$, G.J. SZÖLLŐSI ${ }^{3}$, SZ. MOLNÁR $^{4}$, L. KARDOS $^{5}$ and \\ L. $\mathrm{SZABO}^{2,6,7,8}$
}

${ }^{1}$ National Healthcare Services Centre, Budapest, Hungary

${ }^{2}$ Doctoral School of Health Sciences, Semmelweis University, Budapest, Hungary

${ }^{3}$ Faculty of Public Health, University of Debrecen, Debrecen, Hungary

${ }^{4}$ Department of Dietetics and Nutrition Sciences, Faculty of Health Sciences, Semmelweis University, Budapest, Hungary

${ }^{5}$ Clinical Department of Infectious Diseases, University of Debrecen, Debrecen, Hungary

${ }^{6}$ Department of Family Care Methodology, Faculty of Health Sciences, Semmelweis University, Budapest, Hungary

${ }^{7}$ Department of Paediatrics-Pulmonology, Heim Pál National Paediatric Institute, Budapest, Hungary

${ }^{8}$ Borsod Abaúj Zemplén County Central Hospital and University Teaching Hospital, Velkey László Child Health Centre, Miskolc, Hungary

Received: October 07, 2020 • Revised manuscript received: November 24, 2020 • Accepted: December 09, 2020 Published online: March 4, 2021

\section{ABSTRACT}

Purpose: Understanding the role of nutrition in the development of children's physical, mental, and motor abilities. Materials/methods: Examination of visiting nurse reports on feeding habits and perceived developmental delays in infants at 1 year of age between 2010 and 2015. Results: Between 0 and 6 months of age the lowest number of new cases $(4.4 / 100,000)$ identified by health screenings can be anticipated among the infants feeding exclusively with breastmilk. We find a similarly low number of identifiable new cases among infants nourished with breastmilk where it is mixed with other nutrients (4.7 new cases) while the most cases of delayed motor development can be anticipated among infants nourished with infant formulae (48.4 new cases). Conclusions: The role of nutrition in infants' motor development is vital, especially breastfeeding. Regular health status checks of infants are inevitably required for the adoption of higher-level health-policy decisions which may induce projects, programmes, and strategies aimed at the improvement of health. Thorough documentation and continuous collection of the pertinent data is likewise requisite.

\section{KEYWORDS}

infant nutrition, motor development, parent questionnaires, layer-specific frequency, visiting health consultant
* Corresponding author.

E-mail: magdolna.kadar@gmail.com

\section{INTRODUCTION}

Deviation from the normal course of psycho-motor development of infants and young children has grown to become one of the very serious paediatric problems worldwide [1]. Some authors found that delays or impediments in the normal development below the age of five may affect as many as 250 million children [2-4]. Several factors influence the ageappropriate, healthy development, with nourishment being of key importance in the bodily, psychical, and mental development of children [5-8]. 
According to a position statement of the World Health Organization (WHO), the starting point of healthy development and optimal growth of children is breastmilk and, therefore, they recommend exclusive breastfeeding from birth until the infant reaches the age of 6 months [9]. It is important to emphasise that breastfeeding is a beneficial factor in the decrease of infant morbidity and mortality, and it boosts the infants' adaptive, cognitive and bodily development [4, 10-12]. Several international surveys found that the risk of delayed development of children who are breastfed for a period longer than 6 months is significantly lower. Such research studies prove the assumption that the duration of breastfeeding has a positive impact on the development of the infants' psycho-motor skills as well [13-16].

Information available about the correlation between various infant feeding practices and delayed development in early childhood is scarce [17]. The American Academy of Pediatrics recommends validated methods and tools for the assessment of children's development. The success of the questionnaires titled Parents' Evaluation of Developmental Status (PDS) and Ages and Stages Questionnaire (ASQ) lies in their easy use and, in addition, in their reliability, with a sensibility of $70-80 \%$, as well as in their specificity [18-21].

The aim of our present study is that we summarise and present a correlative analysis based on the data in reports of territorial health visitors regarding the assessment of the relation between infant feeding practices and their motor development with special attention paid to breastfed infants in the age between their birth and the completion of 6 months. Furthermore, we wish to introduce the questionnaires, developed in Hungary (hereinafter referred to as Parent Questionnaires), that are based on the observations of the parents and to show how such questionnaires can provide useful information on children's development in general and on the development on their motor skills.

\section{MATERIAL AND METHODS}

The data were collected from two sources: the Aggregated Reports of Health Visitors for the time period between 2010 and 2015 regarding the feeding practices of infants upon completion of their first year of age and the aggregated data of the compulsory health screenings of infants upon completion of their first year of age among whom certain inadequacies in their motor development were observed [22].

As a first step in the statistical analysis, we summarised the data on infant nutrition and delayed motor development for the period between 2010 and 2015, which was followed by an analysis of the aggregated data on the database, examining the layer-specific frequencies and 95\% confidence intervals. The possible correlations between infant feeding habits and the changes in motor development observed by the health visitor were determined by calculating a univariate Poisson regression.
The aim of the statistical process was to find out to what extent various nourishing practices could influence motor development. The question whether an assumed rise in the various nourishing practices of infants (by e.g. 100,000 cases), may or may not cause an increase or a decrease in the motor development that is inadequate with the age of the infants concerned was examined.

The explanatory variables used for the analysis were given by indicators of different infant feeding habits:

$\triangleright$ The number of infants nourished exclusively with breastmilk: it means the exclusive breastfeeding of an infant, including the administration of skimmed milk, oral rehydration fluid, vitamins, minerals, medications in drops and syrup.

$\triangleright$ The number of infants mostly breastfed who were also given other liquid nutrients: fluid supplementation means that in addition to exclusive breastfeeding, water and water-based beverages and juices are also given.

$>$ The number of infants nourished with mixed nutrients: according to the definition of mixed feeding, in addition to breast milk, everything else is given - formula, nonhuman milk, and solid foods. In the case of a mixed diet, the proposed breakdown includes a proportion of breast milk more than $80 \%$ and the food ingested is less than $20 \%$.

$>$ The number of infants nourished with formulae: the infant does not receive breast milk at all, but is fed with other food or fluids, including formula and non-human milk [23].

The output variable was the number of the cases where deviations from the normal course of motor development were observed on the health screenings carried out by the health visitors.

The regression coefficient $(b)$ and the $P$-value $(P)$ indicating the significance level were marked in the correlation table. STATA 13 program was used for the analyses.

\section{RESULTS}

The results of layer-specific frequency of infant nourishing in Hungary during the period between 2010 and 2015 are reflected in Table 1 in regional distribution. Regarding the proportion of infants exclusively breastfed/were given only breast milk, the prevalence in Hungary is $35.16 \%$ [35.02-35.31\%] up to 6 months of age, according to health visitors' data. For the proportion of infants who are mostly breastfed but receive fluid supplementation, the national reference was $6.48 \%$ [6.42-6.55\%]. For mixed-fed infants, the national prevalence was $53.97 \%$ [53.83-54.10\%], and for formula-fed infants was 3.4\% [3.59-3.69\%].

Delays were screened and detected on the mandatory screening at the age of 1 and included the assessment of motor development, speech development, social development, physical development (body leanness and malnutrition), as well as visual and auditory development. $15 \%$ of these were reported by health visitors between 2010 and 
Table 1. Distribution of the proportion of different infant feeding habits by region between 2010 and 2015

\begin{tabular}{|c|c|c|c|c|c|c|c|c|c|c|c|c|c|c|c|c|}
\hline \multirow[b]{2}{*}{ Indicator in question/Territory } & \multicolumn{4}{|c|}{$\begin{array}{c}\text { Infants nourished exclusively with } \\
\text { breastmilk }\end{array}$} & \multicolumn{4}{|c|}{$\begin{array}{l}\text { Infants mostly breastfed with the } \\
\text { addition of liquid nutrients }\end{array}$} & \multicolumn{4}{|c|}{$\begin{array}{l}\text { Infants nourished with mixed } \\
\text { nutrients }\end{array}$} & \multicolumn{4}{|c|}{ Infants nourished with formulae } \\
\hline & Number & Freq." & CIL & $\mathrm{CIH}$ & Number & Freq." & CIL & $\mathrm{CIH}$ & Number & Freq." & $\mathrm{CIL}$ & $\mathrm{CIH}$ & Number & Freq." & $\mathrm{CIL}$ & $\mathrm{CIH}$ \\
\hline & 17,330 & $28.02 \%$ & 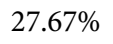 & 8380 & 3,653 & 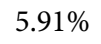 & 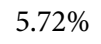 & 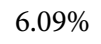 & 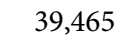 & 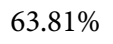 & 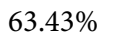 & $64.19 \%$ & 1,317 & $\%$ & $\%$ & 2.24 \\
\hline & & & & & & & & & & & & & 2,0 & & & 4.73 \\
\hline No & 21,689 & $26.77 \%$ & 26.4 & $\%$ & 11 & $7 \%$ & $9.07 \%$ & $\%$ & 45,980 & $56.75 \%$ & $\%$ & $57.09 \%$ & 5,733 & $7.08 \%$ & $6.90 \%$ & $7.25 \%$ \\
\hline No & 17,516 & $27.56 \%$ & $27.21 \%$ & $27.91 \%$ & & & $8.21 \%$ & & 76 & $23 \%$ & & 60. & 2,395 & $3.77 \%$ & $3.62 \%$ & $3.92 \%$ \\
\hline Centra & 21,678 & $8.71 \%$ & $38.31 \%$ & $39.12 \%$ & & & $5.16 \%$ & & 29,759 & $53.14 \%$ & $52.73 \%$ & $53.56 \%$ & 1,515 & $2.71 \%$ & $2.57 \%$ & $2.84 \%$ \\
\hline Pest county & 32,878 & $43.08 \%$ & $42.72 \%$ & $43.43 \%$ & 5,568 & $7.29 \%$ & $7.11 \%$ & $7.48 \%$ & 35,385 & $46.36 \%$ & $46.01 \%$ & $46.71 \%$ & 2,353 & $3.08 \%$ & $2.96 \%$ & $3.21 \%$ \\
\hline Budapest & 40,614 & $43.54 \%$ & $43.23 \%$ & $43.86 \%$ & 4,971 & $5.33 \%$ & $5.19 \%$ & $5.47 \%$ & 45,125 & $48.38 \%$ & $48.06 \%$ & $48.70 \%$ & 2,503 & $2.68 \%$ & $2.58 \%$ & $2.79 \%$ \\
\hline Weste & 19,417 & $40.25 \%$ & $39.81 \%$ & $40.69 \%$ & 2,101 & $4.35 \%$ & $4.17 \%$ & $4.54 \%$ & 25,469 & $52.79 \%$ & $52.35 \%$ & $53.24 \%$ & 1,261 & $2.61 \%$ & $2.47 \%$ & $2.76 \%$ \\
\hline National frequency & 188,175 & $35.82 \%$ & $35.69 \%$ & $35.95 \%$ & 34,067 & $6.48 \%$ & $6.42 \%$ & $6.55 \%$ & 283,521 & $53.97 \%$ & $53.83 \%$ & $54.10 \%$ & 19,124 & $3.64 \%$ & $3.59 \%$ & $3.69 \%$ \\
\hline
\end{tabular}

CIL - Confidence interval-lower bound.

$\mathrm{CIH}$ - Confidence interval-upper bound.

* Layer-specific frequency. 
Table 2. The number of cases of motor development delays during screenings at 1 year of age between 2010 and 2015

\begin{tabular}{lcccr}
\hline & \multirow{2}{*}{$\begin{array}{c}\text { Number of infants screened } \\
\text { at the age of 1 year }\end{array}$} & \multicolumn{2}{c}{ Discrepancies identified during screenings by health visitors } \\
\cline { 2 - 5 } & $\begin{array}{c}\text { Total number } \\
\text { of infants }\end{array}$ & $\begin{array}{c}\text { Identified cases of delayed } \\
\text { movement development (\%) }\end{array}$ \\
\hline 2010 & 91,674 & 22,780 & 3,588 & 15.7 \\
2011 & 85,837 & 21,421 & 3,521 & 16.4 \\
2012 & 83,099 & 20,045 & 3,207 & 15.9 \\
2013 & 85,625 & 22,223 & 2,884 & 16.1 \\
2014 & 80,501 & 20,760 & 3,228 & 13.6 \\
2015 & 80,501 & 23,672 & & \\
\hline
\end{tabular}

Table 3. Correlation of infant feeding habits with the number of cases in the field of motor development during the examination of health visitors at the age of 1 year

\begin{tabular}{lcc}
\hline & \multicolumn{2}{c}{$\begin{array}{c}\text { Number of cases of } \\
\text { inadequate movement } \\
\text { development }\end{array}$} \\
\cline { 2 - 3 } & $b / 100000^{*}$ & $P$ \\
\hline Breast milk exclusively & 4.4 & $<0.001$ \\
Liquid nutrients added to breast milk & 33.6 & $<0.001$ \\
Mixed diet & 4.7 & $<0.001$ \\
Nourished with formulae & 48.4 & $<0.001$ \\
\hline
\end{tabular}

"This indicates the number of new cases of inadequate motor development that would be identified assuming a 100,000 growth of each respective group characterised by different types of nourishment given to infants.

2015 due to lack of motor development. It is shown in detail in Table 2. The nationwide prevalence was $3.88 \%$.

Based on the analysis of the possible correlations between infant feeding and motor development, there was a statistically significant $(P<0.001)$ correlation between the changes observed in motor development and the different infant feeding habits (Table 3).

According to the results and the interpretation of the table, if the number of infants exclusively breastfed increased by 100,000 , the number of cases of motor development would increase with 4.4 new cases, in infants receiving mostly breast milk and fluid supplementation the increase would be 33.6 new cases, 4.7 in mixed-fed infants, and 48.4 in artificially fed infants.

\section{DISCUSSION}

The development of infants is influenced by the combined effect of many factors, however, in terms of the life stages of complex development, the most significant changes can be observed in the first year of life. Environmental factors include nutrition that supports the optimal physical, mental, adaptive, and cognitive development of the infant, as well as its resistance to infections and diseases. For the healthy development and growth of infants, exclusive breastfeeding until the age of 6 months is a preventive factor [24].

During the surveyed period, $96 \%$ of the infants were nourished with breastmilk in some quantity. Somewhat more than one third (35.8\%) was exclusively breastfed and the majority of them was nourished with a mixed diet. Each year, the smallest group was artificially fed infants with 3.6\%. Based on the results of the layer-specific frequency, it can be said that the most favourable prevalence in terms of the proportion of infants receiving exclusive breastfeeding/only breast milk was in Central Hungary and Western Transdanubia, while in the Eastern parts of Hungary it was significantly lower than the national average. The WHO has stated that regular monitoring and accurate documentation of exclusive breastfeeding is essential for measurement [25].

Identified delays in motor development among the infants who had completed their first year of age showed a national rate $3.88 \%$. In the years of the study, there was a decrease in the number of newly screened children with motor delay; however, based on the average in the time period examined, about $15 \%$ of all detected delays affected motor development. When observing region by region and county by county, territorial inequalities could be found. The highest incidence was found in the Western Transdanubia (3.82\%), Southern Transdanubia (4.24\%) and Northern Hungarian regions (3.82\%), while there was a lower incidence of delayed motor development compared to the age-appropriate development in Budapest (03.05\% [02.94-03.16\%]), in Pest county (04.36\% [04.21-04.50\%]), and Central-Transdanubia $(3.57 \%)$ regions. In a statistical study of the possible relationships between feeding habits and motor development, the results of the available data from health visitors clearly indicate the possible relationship between the quality of infant feeding and optimal motor development. For infants in the age between 0 and 6 months who are nourished exclusively with breastmilk the lowest incidence rate of delays in their motor development can be predicted. Should the number of infants nourished exclusively with breastmilk increase by 100,000 , the number of newly identified infants with delayed motor development would be anticipated to be as low as 4.4 and the anticipated rate of infants nourished with a mixed diet would be similarly low (4.7 anticipated new cases). Among infants who are nourished with breastmilk but also receive other liquid nutrients, however, the incidence of delayed motor development cases would be almost eight times more and among those nourished by formulae would be almost eleven times more newly identified cases compared to those nourished exclusively with breastmilk. 
Generally speaking, it can be established that out of the varying nourishment practice models, it is exclusive breastfeeding which best supports motor development and nourishment with breastmilk in any quantity is also advantageous from the aspect of the formation of motor skills and contributes to the age-appropriate motor development. As reflected in the surveyed data, nourishing with a mixed diet leads to a similarly advantageous way of development. It can be proved statistically that the number of new problematic cases to be identified can be expected to come from among the infants who are nourished exclusively with formulae and, therefore, our findings also support the public health concept that it is of utmost importance that children are nourished with some quantity of breastmilk every day [18].

The findings of our study as well as those of international surveys unambiguously indicate that the possible correlation between breastfeeding and the children's development calls for further tasks and research efforts. Our results correspond, in part, with the international studies claiming that breastfeeding supports the psycho-motor development of children $[14,15]$, even though several international studies reported that statistically no significant correlation could be found [16, 26].

Between 2007 and 2011 infants of 501 mothers had been monitored in Poland with a focus on the duration of the time allowed for breastfeeding and it was concluded that no significant correlation could be proved at all between the infants' development and the length of the time spent with their feeding with breastmilk [16]. According to data published by Quinn and al in 2001, follow up screening at 5 years of age with the application of the Peabody Picture Vocabulary Test showed better scores of the cognitive development of breastfed children [14]. The findings of a cross section survey of the National Survey of Children's Health (NSCH) carried out in 2003 on a national representative sample of children below the age of 6 proved the correlation between breastfeeding and the motor skills of American children beyond doubt [27]. In Korea in 2010 a longitudinal survey was implemented which concluded that a breastfeeding period exceeding 9 months made a beneficial impact on the cognitive development of Korean infants [28].

In Hungary the reports of the regional network of health visitors provides information about the health status of infants and nourishing practices [17]. The health visitors in Hungary participate in primary care and they collect data and provide reports as required by the applicable laws and the resulting data form one of the most credible databases of Hungary [29]. The data collected and reported by the health visitors make it possible that the collection of data regarding the same indicators is carried out consistently and can be retrieved in retrospection for several years, which makes this database suitable for reviewing the health status of the children between 0 and 6 years of age. Although the aggregated data of the reports of the territorial health visitor services are not suitable for intensive-level statistical analyses, such reports are indispensable for the revelation of territorial inequalities [17].
The programme titled as TÁMOP 6.1.4 Primary Project for Children of Pre-primary-school Age (0-7 years) funded by the European Union and co-financed by the European Social Fund brought a great improvement in the creation of questionnaires for assessing the observations of parents (Parents Questionnaires). The Parents Questionnaires assess the complex development of children in 15 age-groups between their birth and completion of the 7 th year of age focussing on motor capabilities (gross and fine motor skills), perception, cognition, and thinking, as well as on preverbal abilities and communication [30].

Prior to the nation-wide launching of Parents Questionnaires, their testing was carried out with the participation of 25 physicians and 25 health visitors. In the spring of 2013, during the pilot study, Parents Questionnaires were completed about 1,596 children and paediatric screenings of the same children were carried out simultaneously. The answers to the questions of the questionnaire (yes $=0$, perhaps $=1$, no $=3$ ) and the results of the medical screenings (whether further medical examinations were required or not) served as the basis for the statistical analyses, i.e. the determination of the performance indicators of the questionnaires. During the pilot study, further medical examinations were proposed in 101 cases and in 66 cases out of these 101 the Parents Questionnaires also indicated the same need, which results in a sensitivity of $65.3 \%$ [30]. A revised and fine-tuned version of the Parents Questionnaire was introduced in 2020 on the basis of the experience gained from the pilot study.

A large amount of data is available regarding the development of children based on questionnaires designed in Hungary for recording the observations of parents, which help not only an early recognition of inadequacies but also contribute to the formation of a central database on the characteristics of the development of children. Such a database can serve as a basis for the adoption of new professional guidelines in the management of paediatric primary care, developmental neurology, and early intervention. In addition, the results of the validated questionnaires may serve for various epidemiologic analyses focussing on factors that may have an impact on the development of children. Based on the age groups specified in the Parents Questionnaires a sensitivity of about $75 \%$ in each could be achieved with a specificity between 70 and $80 \%$ and analyses and studies could be carried out and prepared regularly regarding the quality of the correlation between the development of children and the different means of infant nourishment.

\section{CONCLUSIONS}

Our study wishes to point out the importance of collecting accurate and reliable data with the aim of exploiting the data collected by health visitors, which could also serve data analyses even on an individual level in addition to making comparisons between various time periods and locations - thereby enabling a continuous follow up on 
children's health. The role of nutrition, especially breastfeeding, is vital in the motor development of infants. Regular health status checks of infants are inevitably required for the adoption of higher-level health-policy decisions which may induce projects, programmes, and strategies aimed at the improvement of health and careful documentation and continuous collection of the pertinent data is likewise requisite.

Ethical approval: This study has been conducted in accordance with Declaration of Helsinki and according to requirements of all local and international standards.

Authors' contribution: MK conceptualised and designed the study, draughted the work, designed the data collection instruments, coordinated and supervised data collection, critically reviewed the manuscript, and approved the final manuscript as submitted, GJSZ crafted the work, coordinated and supervised data collection, approved the final manuscript as submitted, SZM coordinated and supervised data collection, revised the work critically for intellectual content, reviewed the manuscript, and approved the final manuscript as submitted, LK conceptualised and designed the study, carried out the statistical analyses, draughted the initial manuscript, critically reviewed the manuscript, and approved the final manuscript as submitted, LS interpreted the data for the work, revised the work critically for intellectual content, critically reviewed and revised the manuscript, and approved the final manuscript as submitted.

Conflict of interest: The authors declare no conflict of interest and no financial support was received for this study.

\section{REFERENCES}

1. Vameghi R, Akbari SAA, Sajedi F, Sajjadi H, Majd HA. Path analysis association between domestic violence, anxiety, depression and perceived stress in mothers and children's development. Iran J Child Neurol. 2016;10:36-48.

2. Sachdeva S, Amir A, Alam S, Khan Z, Khalique N, Ansari MA. Global developmental delay and its determinants among urban infants and toddlers: a cross sectional study. Indian J Pediatr. 2010; 77:975-80. https://doi.org/10.1007/s12098-010-0151-9.

3. Engle PL, Black MM, Behrman JR, et al. Strategies to avoid the loss of developmental potential in more than 200 million children in the developing world. Lancet. 2007;369:229-42. https://doi.org/10. 1016/S0140-6736(07)60112-3.

4. Grantham-McGregor S, Cheung YB, Cueto S, et al. Developmental potential in the first 5 years for children in developing countries. Lancet 2007;369:60-70. https://doi.org/10.1016/S0140-6736(07)60032-4.

5. Valla L, Wentzel-Larsen T, Hofoss D, Slinnig K. Prevalence of suspected developmental delays in early infancy: results from a regional population-based longitudinal study. BMC Pediat. 2015; 15:215. https://doi.org/10.1186/s12887-015-0528-z.

6. Baker BL, McIntyre L, Blacher J, Crnic K, Edelbrock C, Low C. Pre-school children with and without developmental delay: behaviour problems and parenting stress over time. J Intellect Disabil Res. 2003;47:217-30. https://doi.org/10.1046/j.1365-2788. 2003.00484.x.

7. Emerson E, Einfeld S. Emotional and behavioural difficulties in young children with and without developmental delay: a binational perspective. J Child Psychol Psychiatry. 2010;51:583-93. https://doi.org/10.1111/j.1469-7610.2009.02179.x.

8. Cooijmans K, Beijers R, Rovers A, de Weerth C. Effectiveness of skin-to-skin contact versus care-as-usual in mothers and their full-term infants: study protocol for a parallel-group randomized controlled trial. BMC Pediatr.2017;17:154. https://doi.org/10.1186/ s12887-017-0906-9.

9. World Health Organization. Indicators for assessing infant and young child feeding practices: conclusions of a consensus meeting held 6-8 November 2007 in Washington D.C., USA. [Internet]. Geneva: World Health Organization; 2008. [cited 2020 October 1]. Available from: https://www.who.int/maternal_child_adolescent/ documents/9789241596664/en/.

10. Boix-Amorós A, Martinez-Costa C, Querol A, Collado MC, Mira A. Multiple approaches detect the presence of fungi in human breastmilk samples from healthy mothers. Sci Rep. 2017;7:13016. https://doi.org/10.1038/s41598-017-13270-x.

11. Petherick A. Development: mother's milk: a rich opportunity. Nature. 2010;468:S5-7. https://doi.org/10.1038/468S5a.

12. Inoue M. Binns CW, Otsuka K, Jimba M, Matsubara M. Infant nourishing practices and breastfeeding duration in Japan: a review. Int Breastfeed. J. 2012;7:15. https://doi.org/10.1186/1746-4358-7-15.

13. Yang C, Liu X, Yang Y, et al. Quality of care and suspected developmental delay among children aged 1-59 months: a crosssectional study in 8 counties of rural China. BMC Pediatr. 2019;19: 41. https://doi.org/10.1186/s12887-019-1406-x.

14. Quinn PJ, O'Callaghan M, Williams GM, Najman JM, Andersen MJ, Bor W. The effect of breastfeeding on child development at 5 years: a cohort study. J Paediatr Child Health. 2001;37:465-9. https://doi.org/10.1046/j.1440-1754.2001.00702.x.

15. Angelsen NK, Vik T, Jacobsen G, Bakketeig LS. Breast feeding and cognitive development at age 1 and 5 years. Arch Dis Child. 2001; 85:183-8. https://doi.org/10.1136/adc.85.3.183.

16. Stelmach I, Kwarta P, Jerzynska J, et al. Duration of breastfeeding and psychomotor development in 1-year-old children - polish mother and child cohort study. Int J Occup Med Environ Health. 2019;32(2):175-84. https://doi.org/10.13075/ijomeh.1896.01328.

17. Kádár M, Szőllősi G, Molnár Sz, Szabó L, Mák E. Hazai csecsemőtáplálási szokások a védónői statisztikák tükrében 2011-2015 között [Infant feeding practices in Hungary between 2011 and 2015 as reflected by the statistics of the visiting health consultancy service]. IME. 2018;17:31-6. [Article in Hungarian].

18. Kádár M Szöllősi JG, Garajszki Kissné I, Egri Árváné Cs, Szabó L. Mozgásfejlődés I. Motoros képességek nem megfelelő fejlődését jelző esetek gyakorisága hazánkban a 6 éven aluli gyermekek körében [Motor develoment I. Incidence of cases of inadequate development of motor skills in Hungary among children below the age of 6]. Védőnő. 2019;29:17-23. [Article in Hungarian].

19. Aszmann A. A gyermekek fejlődésének, egészségi állapotának követése, a követés rendszerébe illesztett szürővizsgálatok hazai gyakorlata [Follow up of children's development by health screenings fitted to the follow-up system in Hungary]. Népegészségügy. 2011; 89:336-43. [Article in Hungarian]. 
20. Glascoe FP. Early detection of developmental and behavioural problems. Pediatr Rev. 2000;21:272-9. https://doi.org/10.1542/pir. 21-8-272.

21. Kelly RS, Boulin A, Laranjo N, et al. Metabolomics and communication skills development in children; evidence from the ages and stages questionnaire. Metabolites. 2019;5:42. https://doi.org/10. 3390/metabo9030042.

22. Központi Statisztikai Hival [Hungarian Central Statistical Office]. Egészségügyi Statisztikai Évkönyv 2010-2015 [Yearbooks of Health Statistics 2010-2015] [Internet]. Budapest: KSH; 2015 [cited 2020 October 2]. Available from in Hungarian: http://www.ksh.hu/ katalogus/\#/kiadvanyok.

23. Egészségügyi Szakmai Kollégium Tagozatai és Tanácsai [Sections and Councils of the Professional College of Health]. Az egészséges csecsemő (0-12 hónapos) táplálása [Feeding a healthy baby (0-12 months)] [Internet]. Budapest: Sections and Councils of the Professional College of Health; 2019 [cited 2020 October 2]. Available from in Hungarian: https://kollegium.aeek.hu/(X(1) S(in4xkplvmja1ifa2wspb50yw))/Iranyelvek/Index.

24. Kádár M, Szőllősi G, Molnár Sz, Szabó L, Mák E. Hazai csecsemőtáplálási szokások a védőnői statisztikák tükrében 2011-2015 között [Infant nourishing practices between 2011 and 2015 as reflected by the statistics of the visiting health consultancy services]. IME. 2018;17:3-36. [Article in Hungarian].

25. Khanal V, Lee AH, Scott JA, Karkee R, Binns CW. Implications of methodological differences in measuring the rates of exclusive breastfeeding in Nepal: findings from literature review and cohort study. BMC Pregnancy Childbirth. 2016;16:389. https://doi.org/10. 1186/s12884-016-1180-9.

26. Walfisch A, Sermer C, Cressman A, Koren G. Breast milk and cognitive development the role of confounders: a systematic review. BMJ Open. 2013;23(3):e003259. https://doi.org/10.1136/bmjopen2013-003259.

27. Dee DL, Li R, Lee L-C, Grummer-Strawn LM. Associations between breastnourishing practices and young children's language and motor skill development. Pediatrics. 2007;1:S92-8. https:/doi.org/ 10.1542/peds.2006-2089N.

28. Lee H, Park H, Ha E, et al. Effect of breastfeeding duration on cognitive development in infants: 3-year follow-up study. J Korean Med Sci 2016;31:579-84. https://doi.org/10.3346/jkms.2016.31.4. 579.

29. Moravcsik-Kornyiczki Á, Kósa Zs, Gyulai A, Erdei Jávorné R, Kósa K. Területi egyenlőtlenségek hosszú idősoros elemzése a várandósnők egészségi állapotát vizsgálva [Long-term line analysis of territorial inequalities found through the health screening of pregnant women]. Orv Hetil. 2017;158:1131-42. https://doi.org/10. 1556/650.2017.30799. [Article in Hungarian].

30. Fogarasi A, Kereki J, Berkes A. Szülői megfigyelésen alapuló gyermekfejlödési kérdőív tesztelése [Testing the parents questionnaire regarding the development of children based on parents' observations]. Gyermekgyógyászat, 2017;68:246-52. [Article in Hungarian] 